Still Fighting: The Relationship Between Contemporary

Preemption in the South and the Continued Struggle for Black Worker Rights

RESHA T. SWANSON

SHE/HER

Post-Reconstruction Black Codes implemented throughout the South stunted the economic mobility of Black workers and replicated the free labor system of slavery (Nittle, 2021). While these laws were abandoned or outlawed over time (Nittle, 2021; PBS, 2017), the use of contemporary preemption in Southern states acts as a de facto continuation of Black Codes by barring legislation, often from progressive cities and municipalities, that seeks to strengthen rights and protections for Black workers throughout the region. In order to properly understand the unique racial, political, and economic entanglement between twentyfirst century preemption and the oppression of Black workers, one must first explore the origins of preemption and the history of Black worker oppression in the South. This examination provides the backdrop for modern attempts to suppress Black workers in states like Alabama and Tennessee. A closer look at the deep political divisions between Southern legislatures and urban municipalities in their states offer arguments, though unfounded and insufficient, in favor of preemption, and outline the challenges worker advocates face when addressing the problem. Despite its challenges, it is critical for organizers to continue fighting preemption using creative strategies and to reaffirm the rights and advancement of Black workers.

Keywords: preemption, South, Dillon's Rule, Home Rule, Black Codes, workers, oppression

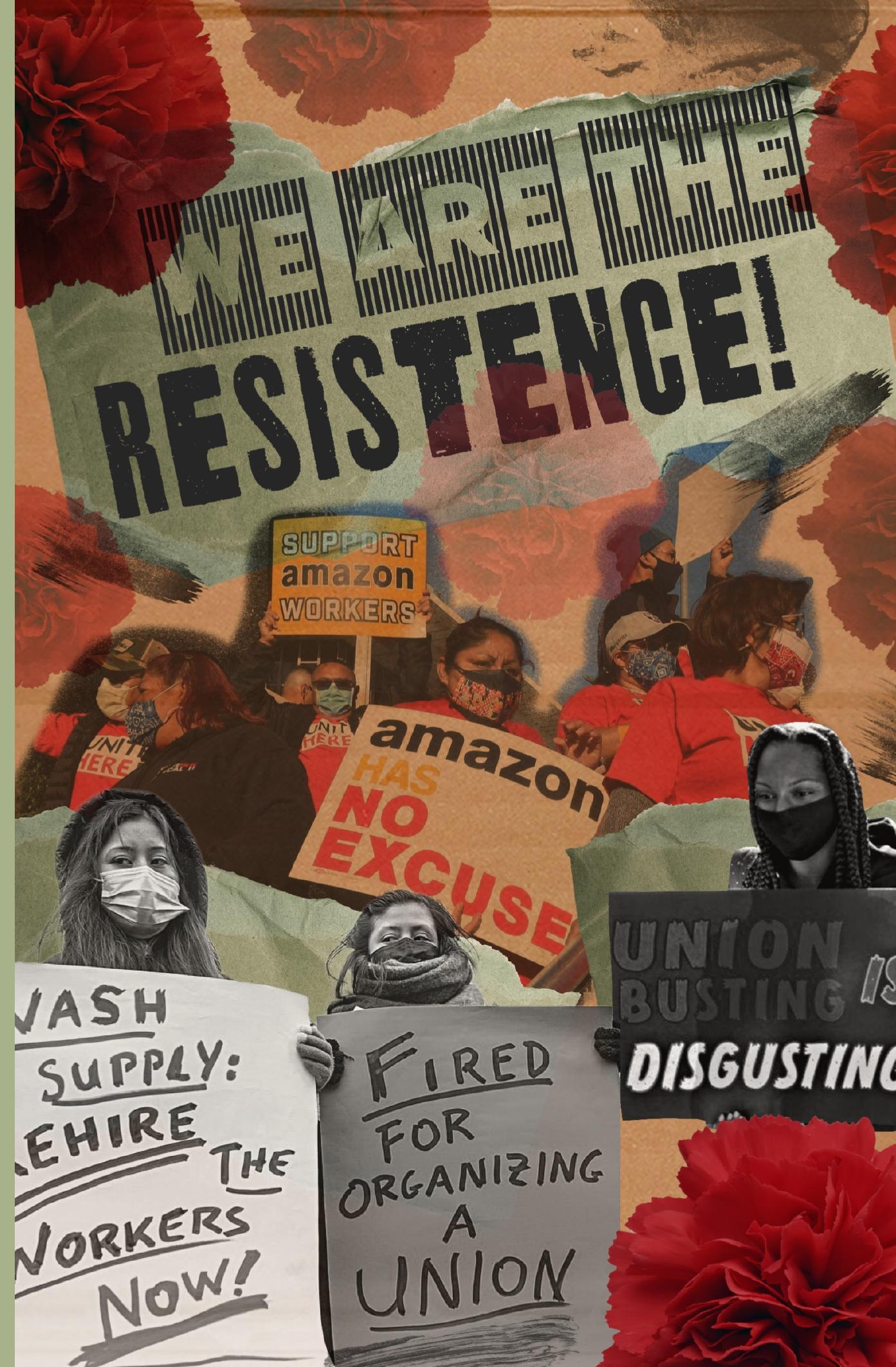




\section{STILL FIGHTING: THE RELATIONSHIP BETWEEN CONTEMPORARY PREEMPTION IN THE SOUTH AND THE CONTINUED STRUGGLE FOR BLACK WORKER RIGHTS}

In the South ${ }^{1}$, where the shadows of slavery loom long and heavy, the word preemption strikes fear into the hearts of local legislators and worker rights advocates. Preemption is the "use of state law to nullify a municipal ordinance or authority" (DuPuis et al., 2018, p. 3). Predominantly white state legislatures use preemption to strike down ordinances passed by progressive cities, including legislation that raises the minimum wage, mandates paid leave, or advocates for fair workweeks. Through it all, workers from these liberal, urban areas with highly concentrated Black populations - often led by Black and Latinx city councils - suffer the economic consequences (Blair et al., 2020). In short, preemption is more than a tool used by state legislatures to block progressive legislation. It is a racially charged mechanism that has been employed for centuries to perpetuate white supremacy and suppress the rights of Black workers in the South.

This paper explores the historical origins of state preemption, its connection to Black worker suppression, and preemption's manifestation in the twenty-first century South. While this paper focuses on the South, it does not mean to express that preemption does not thrive in Northern states or that its effects are felt only by Southern Black workers. To the contrary, preemption oppresses all working class individuals wherever utilized. "State interference with local decision-making occurs in every region of the country" (Blair et al., 2020, p. 3), but preemption in the

1 The Deep South (also known as the Lower South) refers to the states of Alabama, Georgia, Louisiana, Mississippi, and South Carolina, whose economies were historically dependent on the production of cotton and slave labor (Beck \& Tolnay, 1990). The Upper South, composed of Tennessee, Kentucky, and Missouri, relied less heavily on slave labor and traditionally grew wheat and grain-based crops (Jordan, 1967). Scholarly articles vary in their inclusion of Arkansas and Texas as Deep or Upper South states, but agree that they culturally and economically fall within one or both categories (Beck \& Tolnay, 1990; Jordan, 1967). For the purpose of this article, the author uses the term South (and other variations of the word) to refer to states of the Upper and Lower/Deep South areas, and, Texas, Arkansas, North Carolina, and Florida (which share similar economic and cultural histories).
South is distinctly shaped by conservative legislatures battling urban, progressive municipalities and cities, typically heavily populated by Black and Latinx individuals, for legislative power, making Southern preemption uniquely racially divisive (Blair et al., 2020). This paper explores racism's deep-seated role in shaping worker-related preemption policies in the Southern region (Blair et al., 2020).

In order to clearly understand contemporary preemption in the South, we must first study its roots in the United States and its context in the region.

\section{THE FRAMEWORK FOR PREEMPTION}

Two primary factors worked in tandem to set the stage for contemporary preemption-: (1) the Supreme Court conferring preemption powers to states and (2) the restricted economic mobility of Black workers post-Reconstruction.

\section{DILLON'S RULE AND HOME RULE}

The United States Constitution's "Supremacy Clause" clearly defines the hierarchy of authority between federal and state legislation, declaring federal law "the supreme Law of the land" (U.S. Constitution. art. VI, cl. 2.1.1.3). In other words, federal laws overrule state laws in situations where state legislation expressly and impliedly contradicts federal law (Congressional Research Services, 2019). However, the Constitution makes no mention of powers granted to municipalities ${ }^{2}$ and cities and their priority in lieu of less or more restrictive state legislation that does not already contradict federal policy. This left the matter in the hands of various courts.

Named after former Iowa Supreme Court Justice John Dillon, Dillon's Rule "derived from the two court decisions issued by Judge John F. Dillon of Iowa in 1868" (National League of Cities, 2016, para. 4). In the first decision, City of Clinton v. Cedar Rapids and Missouri River

2 In this article, the term municipality refers to counties, wards, and similar governing bodies that function as "political subdivisions of the state" (Phillips, 2017, pp. 2230-2231). 
Railroad Company (1868), "the plaintiff, the City of Clinton, sought to enjoin the defendant, Railroad Company ("Cedar Rapids"), from building railroad tracks across the city's streets without the city's consent" (Hansford, 2020, para. 3). Eventually, "the court held that the city could not prevent Cedar Rapids from building over the streets of the city because the Iowa legislature granted Cedar Rapids the right to do so" (Hansford, 2020, para. 3). Regarding the decision, Judge Dillon wrote:

The true view is this: Municipal corporations owe their origin to, and derive their powers and rights wholly from, the legislature. It breathes into them the breath of life, without which they cannot exist...Unless there is some constitutional limitation on the right, the legislature might, by a single act, if we can suppose it capable of so great a folly and so great a wrong, sweep from existence all of the municipal corporations in the State, and the corporation could not prevent it. We know of no limitation on this right so far as the corporations themselves are concerned. They are, so to phrase it, the mere tenants at will of the legislature. (City of Clinton v. Cedar Rapids and Missouri River Railroad Company, 24 Iowa 455, 475, 1868)

The second key decision, Merriam v. Moody's Executors (1868), challenged a city's ability to "sell and convey real estate for the nonpayment of special taxes" levied in the city's charter (Merriam v. Moody's Executors, 25 Iowa 163, 170). Dillon wrote:

In determining the question now made, it must be taken for settled law, that a municipal corporation possesses and can exercise the following powers and no others: First, those granted in express words; second, those necessarily implied or necessarily incident to the powers expressly granted ; third, those absolutely essential to the declared objects and purposes of the corporation - not simply convenient, but indispensable; fourth, any fair doubt as to the existence of a power is resolved by the courts against the corporation - against the existence of the power. (Merriam v. Moody's Executors, 25 Iowa 163, 170, 1868)

Justice Dillon would expound on what came to be known as "Dillon's Rule" in five editions of his legal treatise Dillon on the Law of
Municipal Corporations (Hansford, 2020). The United States Supreme Court adopted Justice Dillon's analysis in a 1907 decision in Hunter v. Pittsburgh, where the Court declared, "Municipal corporations are political subdivisions of the State, created by it and at all times wholly under its legislative control" (Hunter v. City of Pittsburgh, 207 U.S. 161, 52 L. Ed. 151, 28 S. Ct. 40, 1907).

The most crippling part of Dillon's Rule is the provision that any powers not expressly given to localities have not been conferred, which severely limits municipalities' ability to pass legislation that the state legislature may see as politically unfavorable (National League of Cities, 2016). The National League of Cities (2016) notes, "No local action could be undertaken without permission from the state legislature, which only met for short, biennial sessions... [and] generally requires that local officials spend a considerable amount of time lobbying the state legislature" (para. 6).

Concerned about the restrictive nature of Dillon's Rule, Judge Thomas Cooley held that local governments did possess some power to pass legislation within the bounds of state laws and constitutions (People ex rel. Le Roy v. Hurlbut, 24 Mich. 44, 1871). While Home Rule helped municipalities regain limited power in the early 1900s by "conferring some powers to local governments," its "power is limited to specific fields, and subject to constant judicial interpretation," and was, moreover, defined and applied differently by each state (National League of Cities, 2016, paras. 7-8).

The application of Dillon's Rule and Home Rule is sporadic. Dillon's Rule can be applied to municipalities, cities, or towns with a certain population or chartered before a certain year (or a combination of the two), which is the case in eight states (Russell \& Bostrom, 2016). For example, Alabama applies Dillon's Rule to counties but Home Rule to other municipalities like towns and cities (Hansford, 2020). Some states provide for Home Rule through constitutional changes, while others do it through legislative statutes, and states may limit Home Rule to cities, municipalities, or a combination of the two (Russell \& Bostrom, 2016). 
The uneven application of Dillon's Rule and Home Rule sets the stage for battles over legislative power within states.

\section{A HISTORY OF BLACK WORKER SUPPRESSION}

Another key component to understanding contemporary worker rights preemption is the South's torrid history of Black worker suppression.

The Civil War, followed by Reconstruction, upheaved the lives of Southern aristocrats and governing entities. General Sherman's March to the Sea left thousands of Southerners with damaged or no property, burned cities and fields, and deep-seated resentment (PBS, 2021). In addition to economic loss and extensive property damage, many ruling Southern whites also lost their labor source - enslaved Black people - in the years following the Civil War (PBS, 2021). Reconstruction forced former slave owners to live amongst (at least to some extent) their former "subjects" who, thanks to the newly passed Fourteenth and Fifteenth Amendments, were now endowed (theoretically, at least) with the same inalienable rights, and competed for coveted economic and natural resources (United States Senate, 2021).

Intensified by the tight stranglehold of Reconstructionist Northerners, emancipation threw Southern governments into chaos. When President Hayes reversed Reconstruction in 1877 and withdrew troops, Southern, white lawmakers jumped at the opportunity to "disenfranchise Black voters and dismantle the reforms that had been instituted after the Civil War... and restore the racial hierarchy of the pre Civil War political order" (Blair et al., 2020, p. 5). Black Codes or Black Laws were passed, primarily in Southern states, that successfully "limited the rights of Black people and exploited them as a labor source" (Nittle, 2021, para. 1). These laws created a free labor system that mimicked slavery and served as early examples of Southern legislatures using their power to prevent Black people from gaining economic mobility. Black Codes included state legislation like the following:

In addition to criminalizing joblessness for African Americans, the codes required Black people to sign annual labor contracts that ensured they received the lowest pay possible for their work. The codes contained anti-enticement measures to prevent prospective employers from paying Black workers higher wages than their current employers paid them. Failing to sign a labor contract could result in the offender being arrested, sentenced to unpaid labor or fined (Nittle, 2021, para. 7).

Debt peonage also forced Black individuals into free labor. The meager wages paid to Black individuals post-Reconstruction required many, especially those in the agricultural industry, to take out loans from creditors and sharecroppers (PBS, 2017). Additionally, Black people in the South were targeted and surveilled, often culminating in arrests for minor crimes like loitering and leading to exorbitant court fines and fees. (Nittle, 2021; PBS, 2017). Because they lacked economic means, Black people often were mandated or opted to pay back debts via exploitative free labor (PBS, 2017).

Moreover, Black workers endured vast abuses. Paul Worthman's (1969) early survey of Black workers and their relationship to unions noted the appalling conditions of early mines in Birmingham, Alabama, and the animus of white workers against their Black peers. He wrote, "Racial prejudice among Birmingham workers sometimes broke out into open conflict as white working men attempted to eliminate the economic competition from Black workers by barring them from certain trades" (Worthman, 1969, p. 381). Black workers faced not only verbal and physical conflict, but also financial manipulation and abuse from employers. Worthman (1969) described the conditions at the ore mines of Red Mountain: "Ore was dug by subcontractors who hired laborers at 65 cents per day...whether or not they lived at the camps, at least 50 cent per month was deducted for each man's wages for rent” (p. 397).

Dillon's Rule, early Black Codes, and the economic suppression of Black workers set the stage for volatile legislative conflicts over worker rights across the South. 


\section{TWENTY-FIRST CENTURY PREEMPTION}

Seen through the historical lens of post-Reconstruction, contemporary preemption can be seen as a perhaps more successful continuation of early Black Codes' efforts to limit the mobility of Black workers in the South - successful in the sense of using Dillon's Rule and Home Rule as forces for maintaining a white supremacy that was codified into state law. It is an essential tool for majority white, conservative legislatures hoping to block municipal ordinances that would strengthen the rights of Black workers. The Economic Policy Institute's "Map of the Campaign to Suppress Worker Rights in the States" (2019) indicates that Southern states have some of the most restrictive preemption laws. In these states--Alabama, Arkansas, Florida, Georgia, Louisiana, Mississippi, North Carolina, South Carolina, and Tennessee--state legislatures have stifled local attempts to strengthen worker rights by preempting legislation that altered the minimum wage, established project labor agreements, paid leave, and fair scheduling, instituted prevailing wages, or regulated the gig economy. Unsurprisingly, Black people account for 15\% to $27 \%$ of these states' populations, significantly higher than the national Black population of $13.4 \%$ (U.S. Census Bureau, 2019). Nashville and Birmingham serve as two contemporary examples of preemption in Southern cities and illustrate how its modern-day invocation stifles attempts to expand Black worker rights.

\section{NASHVILLE, TENNESSEE \& LOCAL HIRE LAWS (2015)}

In 2015, Nashville voters passed a local hire ordinance titled Nashville Metro Chamber Amendment Three, which aimed to create job opportunities for city residents. Amendment Three proposed that for "municipally funded construction projects that cost $\$ 100,000$ or more, $40 \%$ of construction work hours must go to Nashville residents, with $25 \%$ of those work hours going to low-income Nashville residents" (Blair et al., 2020, p. 12). In Nashville, $14.5 \%$ of construction workers were Black and $46.2 \%$ were Latinx, and $45 \%$ of all construction workers living in Nashville were born outside the United States (Blair et al., 2020). At that time, $82.6 \%$ of Tennessee State Legislators were white (Blair et al., 2020).
A few weeks later, Tennessee's majority Republican Senate struck down Amendment Three. According to Woodman (2016), "Contractors' associations have opposed local-hiring policies across the country as being anti-competitive, discriminatory to nonresidents, and ultimately a jobkiller" (para. 12). State Senator Jack Johnson, the Republican who spearheaded the bill, and Attorney General Herbert Slatery argued that the local-hire agreement violated the state's standing Contractors Licensing Act of 1994 (Ebert, 2016). When challenged on whether or not his bill was "overturning the will of the voters of Nashville," Senator Johnson answered, "In fact we are" (Ebert, 2016, para. 6). Progressive Nashville worker-organizing groups recognized this as an attempt by the state to stymie liberal work practices and to suppress Black and Latinx workers in progressive municipalities (Woodman, 2016). Jason Freeman, the co-chair of the Nashville Organized for Action and Hope's Economic Equity and Jobs taskforce, responded by saying, "We're trying to get a handle on how to address systemic poverty but the best tools that are available are, one by one, being taken away from us" (Woodman, 2016, para. 16).

\section{BIRMINGHAM, ALABAMA \& MINIMUM WAGE (2016)}

Racism obstructed Birmingham's attempt to pass a minimum wage ordinance in 2016. The City of Birmingham is a majority-minority city, with $70.5 \%$ of residents identifying as Black compared to the state's overall Black population of 26.8\% (U.S. Census Bureau, 2019). In 2016, Birmingham City Council was also majority Black, so it came as no surprise that many saw the City Council's vote to raise Birmingham's minimum wage to $\$ 10.10$ per hour as a significant victory for Black workers. Within two days, the $75 \%$ white Alabama State Legislature passed a bill barring "cities and counties from raising the minimum wage or requiring employers to provide leave or other benefits" (Blair et al., 2020; Roth, 2016, para. 2). The bill applied retroactively, nullifying Birmingham's attempt to rectify economic disparities. There is no state minimum wage in Alabama, so the passage of the bill forced Birmingham to adhere to the federal minimum wage of $\$ 7.25$ per hour. This legislation not only preempted future attempts to raise the minimum 
wage, but it blocked any future efforts by municipalities to strengthen worker rights policies beyond what was enforced by the state.

Alabama's preemption powers derive from the state's adherence to Dillon's Rule. In this case, the Alabama Constitution did not explicitly give municipalities the authority to set minimum wages, so the legislature determined the power to raise the wage was not reasonably implied, and quickly overruled the ordinance. Sixty-five thousand low-wage workers, 28,000 of whom identified as Black, were blocked from receiving higher wages (Blair et al., 2020).

\section{ARGUMENTS IN FAVOR OF PREEMPTION: CONSERVATIVE STATES VERSUS LIBERAL CITIES}

Despite its controversial use, many legislators favor preemption. The liberal metropolitan areas in Southern states are the exceptions, not the norm, in what are otherwise deep red, conservative territories. The liberal politics of urban areas are often met with enormous opposition by Republican constituents, lobbyists, and legislators, which makes statewide coalition building extremely difficult (Adler, 2016). For example, a number of Southern states enforce "right to work" laws, giving oppressed workers little incentive to organize and risk losing their jobs (Shermer, 2018).

Some states see preemption as a tool for protecting rural areas from the threat of liberal cities. Ebert's (2017) article references Texas Lt. Governor Dan Patrick, who remarked:

Where do we have all our problems in America? Not at the state level, run by Republicans, but in our cities that are mostly controlled by Democrat mayors and Democrat city councilmen and women. That's where you see liberal policies. That's where you see high taxes. That's where you see street crime. (para. 17)

Others view preemption as a recourse for stopping "left-wing special interest groups" from implementing liberal policies that do not reflect the will of the majority of the state (Ebert, 2017). Less partisan arguments for preemption claim local autonomy will lead to confusing laws and statutes that will undermine the authority of state governments (DuPuis et al., 2018).

Conservative lawmakers routinely frame progressive worker rights strategies as liberal overreach, but it is abundantly clear that preemption policies passed by legislatures do not hold the best interest of workers at heart nor acknowledge the legislations' disparate racial affect. (K.W., 2017; Graham, 2017). The cases of Birmingham and Nashville make it clear that preemption is not only a way to limit the power of more diverse cities in the South; more seriously, it codifies the oppression of Black workers and limits their access to quality jobs.

\section{WORKERS FIGHT BACK: STRATEGIES TO CIRCUMVENT PREEMPTION}

Despite numerous obstacles, advocates and policymakers have made some headway against preemption and found intersectional, contemporary strategies for a contemporary problem. Cohen (2017) pairs traditional worker advocacy with creative techniques to create solutions that challenge contemporary preemption - for example, lobbying, using municipal administrative powers, and legally challenging legislatures.

Cohen (2017) argues that the first and perhaps the most obvious way to challenge legislatures is by lobbying and forming diverse coalitions among cities with the aim of strengthening the power of local municipalities, amending legislation, and asking legislatures to end preemption permanently. For example, "A coalition of grassroots groups in Louisiana have been lobbying state leaders for at least the past five years to lift families out of poverty through an across-the-board wage increase" (Partnership for Working Families, 2019, p. 8). Of course, this strategy seldom yields results in states with "strong red/blue divide or anti-urban animus" like the South (Cohen, 2017, para. 6).

Cities may also take legal action to halt preemption (Cohen, 2017). Avenues for legal recourse include "claiming that a preemption bill discriminates against a protected class, impinges on a fundamental right, or is motivated by animus" (Bean \& Strano, 2019, p. 21). After 
the Alabama Legislature preempted Birmingham's minimum wage ordinance, several fast food workers and local organizations joined a class action lawsuit. The plaintiffs argued that the State's bill "perpetuates Alabama's de jure policy of white supremacy, in particular its suppression of local black majorities through imposition of white control by state government" (Koplowitz, 2019, para. 4). Unfortunately, the Eleventh Circuit Court of Appeals dismissed the case on an improper filing technicality without considering the merits of the argument (Koplowitz, 2019). Cohen (2017) notes that smaller cities and municipalities with fewer resources may consider joining forces with other organizations, cities, and nonprofits when pursuing financially hefty cases against the state.

Finally, Cohen (2017) asserts that in the absence of legislative power, cities must utilize other powers, such as setting a city policy, creating a new program, or using the so-called power of the purse. Although administration actions (much like Executive Orders) can be repealed and are subject to changing administrations and partisanship, Southern cities like Atlanta and Houston have used administrative means to success in circumventing preemption (Cohen, 2017). Atlanta, for example, increased the city employees' minimum wage to $\$ 15$ an hour over two years by allocating more money to employees' salaries in the city budget, which avoided the state's restrictions on raising municipal wages (Cohen, 2017). To circumvent their Republican legislature's hard-line stance on marijuana legalization, Houston city officials and the county district attorney used their enforcement powers to severely limit the arrest and prosecution of individuals with small amounts of marijuana, "leading to a de facto decriminalization of marijuana" (Cohen, 2017, para. 9; Dart, 2017). In the difficult racial and political context of Southern preemption, this solution may appear most appealing and yield the most success.

\section{CONCLUSION}

From Reconstruction to the new millennium, Southern lawmakers have used preemption to oppress Black workers. Dillon's Rule and post-
Reconstruction Black Codes laid a firm foundation for contemporary Black worker suppression through preemption. Under the guise of exercising state power over "out-of-control" municipalities, twenty-first century conservative lawmakers continue to strike down any attempt to strengthen worker protections made by more progressive (and often more Black) municipalities (Blair et al., 2020). The Alabama State Legislature prevented the passage of Birmingham's ordinance that raised the minimum wage. In Nashville, residents watched as their amendment to implement local-hire was reversed just a few weeks after its passage.

Although deeply-entrenched white supremacy makes the prospect of any immediate progress seem bleak, worker advocates, legal experts, and nonprofit organizations continue to make headway against preemption. Victories in cities like Atlanta and Houston demonstrate the power of lobbying, administrative action, and legal advocacy, and provide a framework for organizers and community members to continue advancing the rights of Black workers.

The racial, political, economic, and community implications and effects of preemption provide the perfect landscape for social work practice. Though social work is not traditionally linked to the fight for workers' rights, modern-day preemption provides micro-, mezzo- and macro-level advocacy opportunities for practitioners--opportunities that demand comprehensive organizing, advocacy, and legislative solutions.

Before his murder, Dr. Martin Luther King Jr. famously supported Memphis sanitation workers striking for better treatment and wages (Craig, 2018). The day before he was assassinated, King delivered a passionate speech on the topic to the Bishop Charles Mason Temple in Memphis. He said:

But then the Good Samaritan came by, and he reversed the question: "If I do not stop to help this man, what will happen to him?" That's the question before you tonight. (Yes) Not, "If I stop to help the sanitation workers, what will happen to my job?" Not, "If I stop to help the sanitation workers, what will happen to all of the hours that I usually spend in my office every day and every week as a pastor?" (Yes) The 
question is not, "If I stop to help this man in need, what will happen to me?" The question is, "If I do not stop to help the sanitation workers, what will happen to them?" That's the question. (King, 1968, para. 30)

As we continue the centuries-old struggle for Black liberation and rights, we must recognize that no worker is truly free until Black workers are free. Freedom starts with challenging preemption in the South.

\section{REFERENCES}

Adler, B. (2016, March 30). State legislatures are undercutting their liberal cities - and are unlikely to stop. Washington Post.

https://www.washingtonpost.com/posteverything/wp/2016/03/30/state-legislatures-are undercutting-their-liberal-cities-and-unlikely-to-stop/

Bauder, D. (2020, July 20). AP says it will capitalize Black but not white. AP News; Associated Press. https://apnews.com/article/7e36c00c5af0436abc09e051261ffflf

Bean, L., \& Strano, M. (2019, July 11). Punching down: How states are suppressing local democracy. New America. newamerica.org/political-reform/reports/punchingdown/

Blair, H., Wolfe, J., \& Worker, J. (2020, September 30). Preempting progress: State interference in local policymaking prevents people of color, women, and low-income workers from making ends meet in the South. Economic Policy Institute. https:// www.epi.org/publication/preemption-in-the-south/

Beck, E. M., \& Tolnay, S. E. (1990). The killing fields of the deep south: The market for cotton and the lynching of blacks, 1882-1930. American Sociological Review, 55(4), 526-539. https://doi.org/10.2307/2095805

City of Clinton v. Cedar Rapids \& Missouri River Railroad (Iowa Supreme Court May 12, 1868). https://cite.case.law/iowa/24/455/

Cohen, M. (2017, July 19). Four ways to fend off state preemption. Bloomberg.com. https://www.bloomberg.com/news/articles/2017-07-19/a-practical-playbook-tobeat-state-preemption

Congressional Research Services. (2019). Federal preemption: A legal primer. Congressional Research Services. https://fas.org/sgp/crs/misc/R45825.pdf

Craig, B. (2018, April 2). Martin Luther King Jr. championed civil rights and unions. AFL-CIO. https://aflcio.org/2018/4/2/martin-luther-king-jr-championed-civilrights-and-unions

Dart, T. (2017, April 18). Houston's new district attorney stands by her bold move to decriminalize marijuana. The Guardian. https://www.theguardian.com/usnews/2017/apr/18/houston-district-attorney-kim-ogg-marijuana-decriminalizationtexas
DuPuis, N., Langan, T., McFarland, C., Panettieri, A., \& Rainwater, B. (2018). City rights in an era of preemption: A state-by-state analysis. National League of Cities. https:// www.nlc.org/wp-content/uploads/2017/02/NLG-SML-Preemption-Report-2017pages.pdf

Ebert, J. (2017, August 16). Divisions escalate between red states and blue cities. El Paso Times. https://www.elpasotimes.com/story/news/politics/texlege/2017/08/15/ exclusive-political divisions-escalate-between-red-states-and-blue-cities/557806001/

Economic Policy Institute. (2019, August). Worker rights preemption in the U.S.: A map of the campaign to suppress worker rights in the states. Economic Policy Institute. https://www.epi.org/preemption-map/

Graham, D. A. (2017, February 2). Progressive cities vs. conservative states. The Atlantic. https://www.theatlantic.com/magazine/archive/2017/03/red-state-bluecity/513857/

Hansford, T. (2020). Dillon's Rule and Home Rule: The history behind the two prevailing views on the powers of local government and what that looks like in Alabama. American Journal of Trial Advocacy, 44(1). https://cumberlandtrialjournal. com/2020/08/11/dillons-rule-and-home-rule-the-history-behind-the-two-prevailingviews-on-the-powers-of-local-government-and-what-that-looks-like-in-alabama/\#_ $\operatorname{edn} 37$

Hunter v. City of Pittsburgh, (United States Supreme Court November 18, 1907). https://cite.case.law/us/207/161/

K.W. (2017, October 9). How conservative states and liberal cities vie for control. The Economist. https://www.economist.com/the-economist-explains/2017/10/09/howconservative-states-and-liberal-cities-vie-for-control

KingJr., M. L. (1968, April 3). I've been to the mountaintop [In-Person]. https:// kinginstitute.stanford.edu/king-papers/documents/ive-been-mountaintop-addressdelivered-bishop-charles-mason-temple

Koplowitz, H. (2019, December 14). Federal appeals court upholds dismissal of Birmingham minimum wage suit. AL.Com; Alabama Media Group. https://www. al.com/news/birmingham/2019/12/federal-appeals-court-upholds-dismissal ofbirmingham-minimum-wage-suit.html

Merriam v. Moody's Executors (Iowa Supreme Court June 25, 2868). https://cite.case. law/iowa/25/163/

National League of Cities. (2016, December 13). Cities 101 - delegation of power. National League of Cities. https://www.nlc.org/resource/cities-101-delegation-ofpower/

Nittle, N. K. (2021, January 28). How the Black Codes Limited African American Progress After the Civil War - HISTORY. www.history.com. https://www.history. $\mathrm{com} /$ news/black-codes-reconstruction-slavery 
Partnership for Working Families. (2019, May). For all of us, by all of us: Challenging state interference to advance gender and racial justice. Partnership for Working Families. https://www.forworkingfamilies.org/sites/default/files/publications/ PWF\%20Gender\%20 Preemption_0.pdf

People ex rel. Le Roy v. Hurlbut (Michigan Supreme Court November 29, 1871). https:// cite.case.law/mich/24/44/

PBS. (2017). Slavery v. peonage. PBS. https://www.pbs.org/tpt/slavery-by-anothername/themes/peonage/

PBS. (2021). Rebuilding the South After the War | American Experience | PBS. Www. pbs.org. https://www.pbs.org/wgbh/americanexperience/features/reconstructionrebuilding-south-after-war/

Phillips, L. E. (2017). Impeding innovation: State preemption of progressive local regulations. Columbia Law Review, 117(8). https://doi.org/

Roth, Z. (2016, February 26). Birmingham Raises Minimum Wage and Alabama Takes it Away. NBC News. https://www.nbcnews.com/news/nbcblk/birmingham-raisesminimum-wage alabama-takes-it-away-n526806

Russell, J. D., \& Bostrom, A. (2016). Federalism, Dillon Rule and Home Rule. In acce.us. American City County Exchange. https://www.alec.org/app/ uploads/2016/01/2016-ACCE-White-Paper-Dillon-House-Rule-Final.pdf

Shermer, E. T. (2018, April 24). The right to work really means the right to work for less. The Washington Post. https://www.washingtonpost.com/news/made-by-history/ wp/2018/04/24/the-right-to-work-really-means-the-right-to-work-for-less/

U.S. Census Bureau. (2019). U.S. Census Bureau QuickFacts: Multiple States. Www. Census.Gov. https://www.census.gov/quickfacts/fact/table/TN,AR,GA,FL,AL,MS/ PST045219?

United States Senate. (2019, February 5). U.S. Senate: Landmark Legislation: Thirteenth, Fourteenth, \& Fifteenth Amendments. Senate.gov. https://www.senate.gov/ artandhistory/history/common/generic/CivilWarAmendments.htm

U.S. Constitution. art. VI, cl. 2.

Woodman, S. (2016, April 4). Nashville Voted To Give Poor People, Locals New Construction Jobs. But the State GOP Blocked It. In These Times. https:// inthesetimes.com/article/republican-prohibition-on-nashville-municipal-local-hires

Worthman, P. B. (1969). Black workers and labor unions in Birmingham, Alabama, 1897-1904. Labor History, 10(3), 375-407. Taylor \& Francis Online. https://doi. org/10.1080/00236566908584085
RESHA SWANSON graduated from the University of Alabama in 2018 with a Bachelor of Social Work and a Bachelor of Arts in Spanish. This spring, she will graduate from Columbia School of Social Work with a Master of Science in Social Work in Advanced Policy Practice concentrating in Contemporary Social Issues. Resha currently lives in Birmingham, Alabama, where she works as a policy coordinator at a low-wage worker center. 